anything more than $5 \mathrm{ft}$. being considered exceptionally large.

There are two main auriferous belts, both running north-east to south-west; the more northerly one, containing all the more famous lodes, such as the Day Dawn and the Brilliant, is about three miles long and three-quarters of a mile wide; the less important southerly belt is of about the same length, but never exceeds 200 yards in width. A small number of scattered mines have been worked outside these belts, but most of these are now closed down. The noteworthy feature of all the lodes is that, whilst the fissures persist in depth, the gold values do not, the mines as a whole showing progressive impoverishment in depth. To quote the author:- "It can be affirmed that pay shoots between the surface and the rooo-ft. level were richer than those between 1000-ft. and 2000-ft. levels, and that these were correspondingly richer than those found below $2000 \mathrm{ft}$."

\section{THE NEW ZEALAND SCIENCE CONGRESS, I919.}

NEW ZE.ALAND occupies a unique and advantageous position for scientific work. Situated in the midst of the vast Pacific, she has splendid opportunities for the pursuit of the fascinating studies of oceanography and the meteorology and astronomy of the southern hemisphere. Innumerable problems in geography, geology, and physiography, of an entirely novel and supremely interesting kind, present themselves, not only in New Zealand itself, but also in the surrounding Pacific and further south in the mysteries of the Antarctic. In her flora and fauna and native races, in her varied mineral wealth, in her large reserves of water-power, both fluvial and tidal, there are endless opportunities for the man of science. In her political, social, and eoonomic institutions she is bound to make valuable contributions to experimental sociology; and it is the experimental side that chiefiy matters and stands most in need of encouragement in these days of nebulous theories and unsubstantial visions.

It is perhaps only natural that, in her present stage of development and in view of the smallness of her population, New Zealand should appear to limit her research outlook chiefly to matters of a practical and utilitarian nature. In such a purely agricultural community it is only to be expected that the biological sciences-applied botany and zoology-should occupy a predominant position, as is clearly evidenced by the election of a distinguished botanist as president of the New Zealand Institute and Science Congress, and also by an analysis of the contents of the first fifty volumes of the institute's Transactions. Such analysis discloses that, of the papers contributed, zoology claims I I 43; botany, 654; geology, 503; anthropology, 204; physics (including astronomy and meteorology), I52; chemistry, 135 ; engineering, 76 ; mathematics, 40 ; economics, 37; history, 34; metaphysics, 22 ; medicine, 20; literature, 15 ; education and statistics, 12 each. It must be remembered, however, that many valuable contributions do not appear in the Transactions; some are published in scientific journals in Great Britain; the Geological Bulletins and the Palæontological Bulletins of the New Zealand Government absorb others. The Polynesian Journal takes most of the papers on anthropology.

In commenting on the predominance of the natural history papers, the president, Dr. Cockayne, pointed out that this is only to be expected in a new land with both flora and fauna so little investigated and containing so much that is endemic. Most of the papers are devoted to classification. "This must have been so; it NO. 2620 , VOL. IO4] is the natural evolutionary process in the history of biological research the world over. ... As for chemistry and physics, which make but a poor showing in the work of the New Zealand Institute, little progress can be made in these sciences without well-equipped chemical and physical laboratories and men specially trained in such. Laboratories of this class are now attached to the various university colleges, and chemical and physical contributions-the work of trained students-are slowly but surely finding a place in the Transactions."

When it is remembered that the institute only receives the small sum of $500 l$. per annum as Government grant it is a matter for amazement that so much work has been accomplished. A levy of $200 l$. was made on the affiliated societies, which could ill afford it, but yet there are scarcely funds sufficient to publish the Transactions. Many papers of great value await publication, and much work of national interest awaits initiation. Government financial support and public sympathy are both badly needed, and it is hoped that the Science Congress, the first of its kind in New Zealand, will go far to supply these needs. The Government has, as a matter of fact, promised to do its utmost to place the institute on a firm financial footing, and has already made special grants for economic science.

The New Zealand Institute consists of a number of incorporated societies, namely, the Auckland Institute, the Wellington Philosophical Society, the Philosophical Institute of Canterbury, the Otago Institute, the Hawke's Bay Philosophical Institute, the Poverty Bay Institute, the Manawatu Philosophical Society, the Wanganui Philosophical Society, and the Nelson Institute. The management of the New Zealand Institute is vested in a board of governors representative of the incorporated societies and of the Government, and this board meets annually in Wellington in January.

The Science Congress, organised by the institute this year and held in Canterbury, was the first of its kind in the Dominion, and owed its inception largely to proposals for the reform of the institute made by Dr. J. Allan Thomson in 1917. Dr. Thomson said: "In its relation to the public the New Zealand Institute should, but does not, hold a position analogous to that of the British Association for the Advancement of Science, the body which most keeps the public in touch with science, and from which most of the im. provements in the State attitude to science have had their origin. The Australasian Institute for the Advancement of Science meets too seldom in New Zealand to be effective in this direction." The Congress was opened by the Governor-General of the Dominion, who, in his address, enumerated four important matters for investigation and study, namely, ( $\mathrm{I}$ ) public health and pandemic disease; (2) afforestation; (3) the mineral oil industry; and (4) fisheries. The Hon. G. W. Russe1l, Minister of Internal Affairs, urged the development of natural resources, especially hydroelectric power, and promised the institute adequate financial support. "The State must be prepared to foot the bill. I therefore urge the Science Congress to press upon the Grovernment that without Governmental expenditure science cannot grow and expand; that scientists cannot live on air or on the hope of posthumous fame; and that therefore if the Dominion is to develop by means of science, adequate funds must be provided for research, for the training of teachers and professors, for the equipment of laboratories and staffs, and for the creation of the scientific atmosphere of which I have spoken."

The president of the Congress (and of the New Zealand Institute), Dr. L. Cockayne, gave a brief 
historical account of the institute and described its immediate aims and aspirations. These are mostly agricultural at present, and in such a farming community nothing demands years of close study more than the soil itself. The world over, soil science, notwithstanding many books on the subject, is in its infancy. Chemical analysis of a soil, even with far better methods than those now available, is only one part of the question. The extremely difficult problems of soil-physics at once confront the investigator. Then there is the rich soil-flora and the rich soilfauna. When more of a fundamental character is known as to the relation of soil-physics, soil-chemistry, and soil-biology to one another, then, said the president, undoubtedly new methods of soil-utilisation will be in sight. In the domain of anthropology Dr. Cockayne made the interesting suggestion that there is no need to confine one's investigations to primitive races, for amongst the settlers in a new land evolution in certain directions goes on apace. The question of dialect, for instance, among the white people of New Zealand would form a valuable study.

Although the presidential address was mostly biological, it is sufficiently evident, from an examination of the numerous and varied papers read, that other important branches of science are not to be overlooked by the institute. Section I, Biology and Agriculture, had several papers of value and interest to the agriculturist, concluding with one by Sir' James Wilson on "Agriculture's Debt to Science." Section 2, Geology, had papers on "The Older Gravels of North Canterbury," by R. Speight; "The Significant Features of Reef-bordered Coasts," by W. M. Davis; "Rough Ridge, Otago, and its Splintered Fault-scarp," by C. A. Cotton; "Natural Features of the Arthur's Pass Tunnel," by F. W. Hilgendorf and others; and "Geology of the Middle Clarence and Ure Valleys," by J. Allan Thomson. These and other papers will ultimately appear in the Transactions. Dr. Thomson also gave some interesting notes on the geology and palæontology of the Palliser Bay district, and a quantitative study of the silica-saturation of igneous rocks, suggesting a valuable means of comparing rock analyses. About a thousand such analyses have been calculated and plotted, and it is hoped to continue the work with the aid of a Government research grant.

$\mathrm{Mr}$. E. K. Lomas dealt with some of the educational aspects of geography, and his opening remarks are well worth quoting: "Education, from one point of view, consists in bringing a mind into close touch with its environment through the senses. The more often the mind is roused to activity by excitations from the outside the more it develops. The special section of the environment in which we are particularly interested--I speak to a meeting of geologists--is that included under the term 'geology'; and the only means we have of introducing our subject into the schools is through the medium of geography, so that this subject should be an object of lively interest to all present. And there is no doubt about it, we shall have to take more interest in the subject for several reasons: (I) it is developing rapidly, (2) it is eminently suitable for educational purposes, (3) the present ignorance of geography is truly alarming and deplorable." If this be true of New Zealand, with its excellent educational system, it is still more applicable to this country. One of the most valuable papers in the geology saction was "The Organisation and Functions of a State Geological Survev," by Mr. P. G. Morgan. This gave a brief account of most of the existing State geological surveys in the United Kingdom, Europe, India, Canada, the United States, Aus. tralia, and New Zealand, with suggestions for the NO. 2620, VOL. IO4] organisation of such surveys in general and for New Zealand in particular.

In Section 3, Chemistry, Physics, and Engineering, Mr. D. M. Y. Sommerville described an improved planisphere and a slide rule for solving the quadratic equation. Dr. C. E. Adams, Government Astronomer, read a paper on "Tables of Mathematical Functions.' Mr. Evan Parry, Government Electrical Engineer in New Zealand, said these tables constructed by Dr. Adams were of great value, for the ordinary tables of natural logarithms were not sufficiently minute for practical use in electrical work. Dr. Adams also gave another very interesting paper on "The Harmonic Analysis of Tidal Observations and the Prediction of Tides." No arithmetical approximations are used, so that a criterion is obtained with which to test the application of Fourier's series to tidal observations. The method of tide-prediction used in New Zealand is a graphic one, controlled by calculation, and is fully illustrated and described in the Survey Reports of the Lands and Survey Department for the years r9Io-I4. The results for Wellington and Auckland are published in the New Zealand Nautical Almanac by the Marine Department.

In his paper on "The Porosity of Porcelain," with special reference to high-pressure insulators for electric transmission lines, Mr. C. C. Farr said that the tests were made at the suggestion of the engineers of the Lake Coleridge electric supply system, who desired a method for determining whether the porcelain of the insulators was porous or not. The tests were carried out in the physical laboratory of Canterbury College by immersing specimens of porcelain in a fuchsin or red-ink coloured solution under a pressure of $2000 \mathrm{lb}$. per square inch, the solution being contained in a hole 3 in. in diameter and $6 \frac{1}{2}$ in. deep bored in a block of solid steel and covered with a steel cap $I$ in. thick and a leather washer by means of eight bolts. Both glazed and unglazed porcelain was subjected to test, and it was concluded from the results that (r) density and porosity have little or no connection with each other, (2) porcelain can be made which shows no penetration after fifty hours' immersion under the pressure named, (3) porcelain is not always so made, and may contain a porous layer with abrupt edges in the mass of the substance. The experiments are being continued.

In a paper on "The Interference of Power Circuits with Telephone Circuits" Mr. E. Parry presented a mathematical treatment of the subject, as complete as possible, with the view of co-ordinating results of past experience and enabling effects to be predicted under given conditions, with special reference to the Lake Coleridge transmission lines. The New Zealand Public Works Department, together with the Post and Telegraph Department, has for some time been studying the influence of power circuits on telegraph and telephone circuits, since the wires for both services are supported on the same poles.

In Mr. E. E. Stark's paper on "The Effect of Low Power-factor from the Viewpoint of Electric Power Station Operators" it was suggested that the power stations using the alternating current system should charge the consumer for the total current taken, including both power-producing and wattless currentthat is to say, the charge should be based on kilovolt amperes instead of kilowatts. If it is desired to equalise the rates without raising the price of electricity, an average power factor could be taken on a given system and a reductión made. Mr. H. Hill read a paper on "National Hydro-electric Schemes for New Zealand," in which he said it was difficult to understand the delay in formulating a national elec- 
tric scheme for the Dominion. Mr. E. Parry's great North Island scheme should be put in hand at once, including the electrification of the East Coast railway. The people in the South Island also should insist on a national scheme.

Dr. Adams, in addition to his papers already noted, read others on ( 1 ) "Determination of the Position of the Moon by Photography," illustrated by photographs from the Lick Observatory. The very fine star images secured indicate the high efficiency of the Crossley reflector telescope, which was driven without any guiding, and the photographs prove that the position of the moon and terrestrial longitude can be determined with high precision. (2) "The Almucantar Method for Determination of "Time and Latitude." (3) "A Nomogram for Transit Instrument Star Factors." Dr. Adams exhibited also some photographs on glass of the solar corona received by the Hector Observatory from Dr. W. W. Campbell, of the Lick Observatory in California. The photographs were taken by the Crocker Eclipse Expedition on June 8 , 1918 , at the total eclipse of the sun, with a $40-\mathrm{ft}$. camera pointed directly at the sun, and using 10 in. by 12 in. plates. The Lick Observatory had most remarkably good fortune at this eclipse: the sky had been completely cloudy all day, but cleared up in the neighbourhood of the sun one minute before totality, and this small portion of the sky remained clear until a few seconds after totality. The small region of unclouded sky containing the totally eclipsed sun seemed to be quite clear and was the bluest sky seen by the expedition.

Section 4, General, had papers on "Moriori Art," by Mr. H. D. Skinner, lecturer on ethnology at Otago University; "The Language of the Chatham Islands," by Archdeacon H. W. Williams; and "The Natural Laws of Poetry," by Mr. J. C. Andersen. The following papers, read in the General Section, should more properly have been included in Section I, viz. "Afforestation in New Zealand," by Mr. W. H. Skinner; "Some Proposals with regard to Natural Afforestation in a New Zealand Mountain Area," by Mr. W. G. Morrison; and "Preservation of New Zealand Fauna," by Mr. E. G. Stead.

\section{THE AFRICAN RIFT VALLEY.1}

$A$ FTER the discovery of Lake Rudolf in 1888 , Suess showed that the Jordan, Dead Sea, and Red Sea fractures were not continued along the coast of Africa, but through the East African lake chain, the basins of which had been formed by the foundering of their floors between parallel faults. During an expedition to British East Africa in 1892-93 Prof. Gregory confirmed Suess's conclusions, with some modifications as to the age and origin of the Great Rift Valley, the formation of which he attributed to successive faulting during the great earth movements of the Kainozoic era.

The Rift Valley has been traced from northern Palestine to southern Africa. Its structure varies with its age and the nature of the country traversed. Thus the fault-scarps are better preserved along the Gulf of Akabah than in the older sections which enclose the Red Sea and the Gulf of Suez. The section in southern Abyssinia which connects the Red Sea with Lake Rudolf and the Rift Valley in British East Africa is locally irregular where intersected by the cross fractures that bound the sunk land of the Gulf of Aden. Across British East Africa the valley is a

1 From a paper read before the Rnyal Ge graphical Society on January 5 by Prof. J. W. Gregory, F.R.S. NO. 2620 , VOL. IO4] comparatively simple trench; its walls are often so steep that Sir John Bland-Sutton describes them as "as steep and abrupt as those of a grave," and for long the Uganda Railway worked its trains between the valley and plateau by a rope incline, and there is still no road for wheeled traffic from Nairobi to the floor of the Rift Valley.

South of British East Africa it has been claimed that the Rift Valley comes to an end, only its western wall being continued as a fault-scarp. This arrangement occurs near Lake Manyara, where the eastern side is a long, smooth slope which ends westward at the foot of the fault-scarp that bounds the Giant Cauldron Mountains. The structure may be explained as an extreme case of the asymmetry due to the different strengths of the rocks on the two walls. In southern British East Africa at Lage Magadi the western wall is a high, steep scarp, while the eastern side consists of a number of wide, flat steps due to parallel faults. At Lake Manyara, as the rocks on the eastern side are softer, the scarp has been dressed down to an even slope. This arrangement does not extend far; the eastern wall soon reappears, and, though Suess left a gap of $35^{\circ}$ miles long between Lakes Manyara and Nyasa, the Rift Valley has now been traced across most of it.

That Nyasa is a Rift Valley basin has been proved by Andrews and Bailey. Its northern end is joined by the western branch, which includes Tanganyika, the Albert Nyanza, and the Upper White Nile. In the western branch the valley is in places irregular, as branches run off or the course is deflected along the grain of the country, to which that branch as a whole is oblique. South of the Zambezi the Rift Valley has been traced by Teale and Wilson, who have shown that a post-Eocene rift valley separates the Sheringoma plateau from the eastern front of Rhodesia. The long meridional section of the coast from Beira to Cape Corrientes appears to have been determined by the southernmost of the crustal movements of the Great Rift Valley.

The valley, therefore, extends from Lebanon to the Sabi River; its branches reach the mouth of the Gulf of Aden, and westward include the rift valleys of the Eastern Congo. Its length is about one-sixth of the circumference of the earth; hence it must have had some world-wide cause, the first clue to which is its age. The view that its history is geologically short commends itself by the freshness of its walls, by the legends of catastrophes, such as the destruction of Sodom and Gomorrah and the drowning of many villages on the formation of Tanganyika, having occurred along it during the time of man, and also bv the fact that many of its faults are certainly recent. Nevertheless, the fuller evidence now available confirms the classification advanced in 1896 , which attributed some of its lavas to the time of Chalk, and represented some of its faults as older than the uplift of the Alps. Some beds attributed to the Miocene on physiographical evidence are now proved of that date by the evidence of fossils. The rift vallev of the Red Sea was certainly in existence by the Oligocene, and the southern end of the valley is shown to be of the same date by a fossil sea-urchin which has now been proved to be an East African species.

The history of the Rift Valley is largely denendent on the volcanic history of the country traversed. The first step in its formation was the uplift of a broad band of highlands extending from Palestine to Natal. The weakening of the support led to the collapse of the summit of this ridge. The sinking of the keystone caused volcanic eruptions along the adjacent fractures. The earliest of the great eruptions probably 